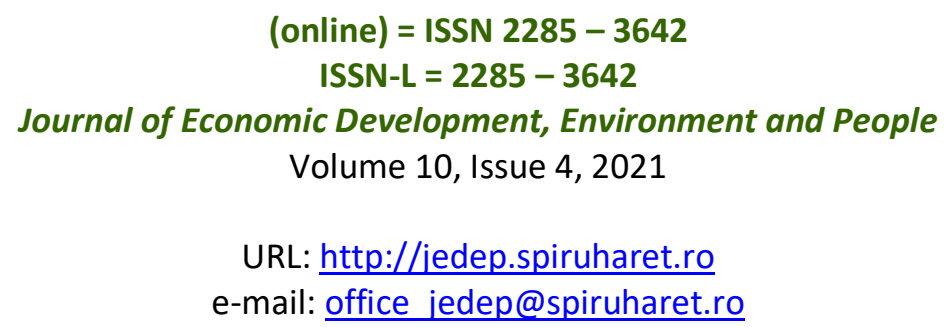

URL: http://jedep.spiruharet.ro e-mail: office jedep@spiruharet.ro

\title{
Consumers' Perception of The Cost of Credit Default in The Vehicle Finance Industry in South Africa
}

\author{
Nomaphelo Soga ${ }^{1}$, Darlington P Onojaefe ${ }^{2}$, Lawrence Obokoh ${ }^{3}$, Wilfred I Ukpere ${ }^{4}$ \\ ${ }^{1}$ Department of Cost and Management Accounting, Cape peninsula University of \\ Technology, South Africa \\ Email: Nomaphelo.soga@standardbank.co.za
}

${ }^{2}$ Graduate Centre for Management, Cape Peninsula University of Technology, Cape Town, South Africa

Email: Onojaefed@cput.ac.za
${ }^{3}$ Department of Cost and Management Accounting, Cape peninsula University of Technology, Cape Town, South Africa
Email: Obokohl@cput.ac.za

${ }^{4}$ Department of Industrial Psychology and People Management, School of Management, College of Business \& Economics, University of Johannesburg, South Africa,

Email: wiukpere@uj.ac.za

Corresponding Author: Wilfred Ukpere (+27735295587)

Email: wiukpere@uj.ac.za 


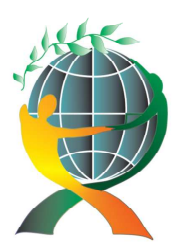

\author{
(online) $=$ ISSN $2285-3642$ \\ ISSN-L = $2285-3642$ \\ Journal of Economic Development, Environment and People \\ Volume 10, Issue 4, 2021
}

URL: http://jedep.spiruharet.ro

e-mail: office jedep@spiruharet.ro

\begin{abstract}
The risk that a borrower may not fulfil his/her borrowing obligation presents credit owner (lender) a default risk management opportunity to maximize the risk-adjusted rate of return and to maintain minimum exposure to default associated cost. This paper investigated respondents' perception of the cost of credit default and examines requirements for default risk management (DRM) in the vehicle finance industry in South Africa. It is noted that with an increased level of consumer indebtedness, unstable economy, high unemployment, opportunistic risks like health pandemics, vehicle financing faces a higher probability of default from borrowers. This descriptive investigation utilised quantitative approach using a survey method to collect data from 381 purposive randomly selected respondents who are vehicle finance customers in South Africa, Cape Town specifically. Data collection took place in the Western Cape over a nine-month period, utilising personal interview, and emails to administer questionnaires to vehicle finances' customers as data collection instruments. Responses received were codified and quantitative data were analysed using the Statistical Packages for Social Sciences (SPSS version 25) The paper found mixed and variable respondents' perception of the cost of credit default. In conclusion, it is perceived that South Africa debt would become more costly with credit default. It can be recommended that a default risk management intervention be applied to manage credit default risk within the context of the unified credit assessment policy in South Africa.
\end{abstract}

Keywords: Finance cost, customers, financial institutions, and credit default risk

JEL Code: G32

How to cite: Soga, N., Obokoh, L., Onojaefe, D., \& Ukpere, W. (2021). Consumers' Perception of The Cost of Credit Default in The Vehicle Finance Industry in South Africa. Journal of Economic Development, Environment and People, 10(4). doi:http://dx.doi.org/10.26458/jedep.v10i4.721

\title{
1.Introduction
}

The vehicle finance enables the provision of credit finance services to support the financing of vehicle on credit. This paper investigates the default risk associated with credit financing of motor vehicle in South Africa - to understand potential risk mitigating factors needed to manage the cost of credit defaulting. With increased household debt, the risk of credit default is at an all-time high, requiring a new approach to assess and approve credit vehicle finance application (Schwarz, 2011). It can be argued that the assessment requirement may need to be varied in the context of growing household indebtedness and government regulation as a risk management measure. The variation of credit assessment outcome of cost management is assumed to be complex and trans-disciplinary 


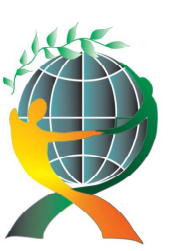

\author{
(online) $=$ ISSN $2285-3642$ \\ ISSN-L = 2285 - 3642 \\ Journal of Economic Development, Environment and People \\ Volume 10, Issue 4, 2021
}

URL: http://jedep.spiruharet.ro

e-mail: office jedep@spiruharet.ro

requiring different approaches and techniques that involve both quantitative and qualitative methods (Brown \& Moles, 2014).

The assumption that there are costs of credit default creates the need to do credit checks on potential customers. This credit check enables the estimation of probability of credit default by customers. The credit check is done to minimize the risk associated with default and to maximize the benefit of credit financing. Despite the credit checks, it has been observed that customers default in their instalment resulting in the repossession of their vehicles by the financial institution.

The understanding of the cost of credit default in the vehicle finance sector is a step towards default risk identification and management: an important aspect of risk management success. Credit has costs on credit, and it is risky as some of the customers may not be able to repay their vehicle finance obligations. Even when customers' probability of default has been assessed upfront and credit checks performed positively, some customers still default. The estimation of the cost of credit default indicates the likelihood of loss arising from credit financing. The cost of default is an important component of cost of banking operations as it offers an understanding of different behaviours of default rates and institution's financial position. Customers may pass the screening process prior to the grating of vehicle finance and yet they end up defaulting, due to bad financial management or unforeseen circumstances. This study focuses on the cost implications of credit default on customers and the financial institution.

\title{
1.1 Scope of the study
}

The scope of the study is the extent to which the actual cost of credit default is evaluated through an examination of customers' perception. The evaluation covers respondents on default list of vehicle financed by financial institution. The costs of credit default is understook differently by customers and banks. The difference in understanding creates the need to do credit checks on potential customers to assess the probability of credit default by customers. The credit check is done to minimize the risk associated with default and to maximize the benefit of credit financing. Here attention is giving to customers' perception of credit default.

\section{The objective of the study}

The main objective of this study is to examine customer perception of credit default using the unified credit risk policy to understand customers understanding the cost of default . The study has the following as sub-objective are to:

(1) Understand the risk associate with the application of credit assessemt tool and 


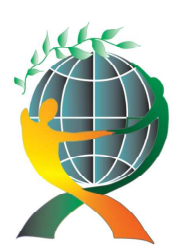

\author{
(online) $=$ ISSN $2285-3642$ \\ ISSN-L = $2285-3642$ \\ Journal of Economic Development, Environment and People \\ Volume 10, Issue 4, 2021 \\ URL: http://jedep.spiruharet.ro \\ e-mail: office jedep@spiruharet.ro
}

(2) Ascertain through customer perceive risk of default if the utilization predictor variables correctly predict the likelihood of customer credit defaults.

\title{
3. Study implication
}

The implication of this study is that credit default is perceived to be costly to both customers and financial institution. Financial institution could benefit through customer perception deploy risk mitigation compartible with credit assessment plicy tool. The actual cost of credit default can be explore in a separate study for the benefit credit financing of motor vehicle in South Africa.

\section{Review of Literature}

Financial institutions' main objective is to generate profit through granting of vehicle finance loans. Even though it is a high-risk business, it is a gamble game that makes business sense, even as some customers may default, which can position the financial institution in a negative financial state. It is imperative that financial institutions learn to understand the cost involved in credit default in order to minimize and manage it. The cost of credit default can be an unpleasant experience for both the customer and the financial institution.

Dumbrava, (2013) contended that the formula for risk calculation: risk = probability (of a default) $x$ loss (associated with default variable) quantifies loss in the event of the occurrence of an event (such as default). In this paper, the examination of the estimated loss connected with credit default (credit structure, economic activities, credit check history and return on investment) are all such events that could contribute to the probability of credit default. Although this study was focused on description of respondents' perception of the cost of credit default, the understanding of respondents' perception created an opportunity to understand the risk management that could be useful for both credit lenders and borrowers.

The cost of credit default can be classified as non-financial and financial loss (Vlok, 2017). Credit costs money and it costs more when customers default. For each vehicle finance institution provision for default is usually calculated through past experiences and a reasonable amount of money is reserved for such, however, it can happen that more clients than anticipated may default, which leaves the financial institution in a compromising financial position. This can cause liquidity problems, less income and more financial loss to the financial institution.

\section{1. Financial loss}




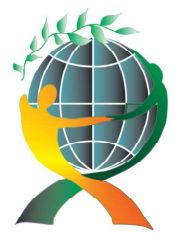

\author{
(online) $=$ ISSN $2285-3642$ \\ ISSN-L = $2285-3642$ \\ Journal of Economic Development, Environment and People \\ Volume 10, Issue 4, 2021
}

URL: http://jedep.spiruharet.ro

e-mail: office jedep@spiruharet.ro

Vehicle repossessions, legal and operational costs are some of the costs incurred caused by defaulting customers. Repossessions can be expensive to both the customer and the financial institution. Once the client defaults, the financial institution starts the legal process, collection department contacts the client to follow up on repayments, and if all fails then a summons is issued by the Sheriff of the Court. The financial institution pays the Sheriff for the summons issued and when the vehicle is uplifted (vehicle gets collected from the customers). These are some of the costs incurred by the financial institution (Jacobs, 2017). Customers also incur financial loss, for instance, once the vehicle has been repossessed, the financial institution adds more costs on the existing debt (for example Sheriff's fees). Once the vehicle is repossessed the customer is left stranded, more debt and in a compromised financial position.

\title{
4.2. Non-financial loss
}

A reputational cost is one of the costs associated with the costs of default. A relationship between the financial institution and a customer can go sour. It has been proven that word of mouth is a powerful advertising tool (Naz, 2014). The customer can lay a complaint on social media, to colleagues, families and friends, as a result, the financial institution can lose millions of rands caused by a tarnished or dented reputation. A customer whose vehicle has been repossessed will not be singing praises about the financial institution. The Basel Committee of Banking Supervision (2003) defined reputation risk as risk arising from negative perception on the part of the customer. Damage to reputation can generate financial loss, broken trust and a tarnished image. For the customer, the effect is high debt incurred through repossessions and loss of trust in the financial institution.

\subsection{Default risk}

The drivers of default risk in the economy are high customer debt, interest rates, inflation, economic performance and unemployment (Bonfim, 2007; Zabai, 2019). These drivers increase the risk of default by a customer obtaining vehicle finance. Instances where the customer is highly indebted, granting additional credit facility could increase exposure to the probability of default. The risk of default could also be influenced by the economic conditions where interest rate fluctuation becomes an element of cost of credit in vehicle financing. Fluctuation in interest rate occasioned by economic conditions becomes an important default risk factor - that provides context to credit financing and content associated with risk of default. Here attention is placed on vehicle financing risk that is contrived by the challenges of risk management and customers' repayment ability that becomes imperative when he/she becomes unemployed Merton (1973). 


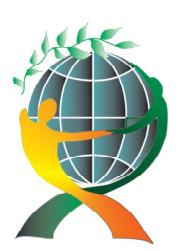

\author{
(online) $=$ ISSN $2285-3642$ \\ ISSN-L = 2285 - 3642 \\ Journal of Economic Development, Environment and People \\ Volume 10, Issue 4, 2021 \\ URL: http://jedep.spiruharet.ro \\ e-mail: office jedep@spiruharet.ro
}

\title{
4.4. The use of the credit checks history for risk assessment
}

Credit checks on customers through the credit bureaus in South Africa came into existence in late 1989. Credit bureau is a company that gathers information on the customer's credit profile. The credit information customers aggregate all credit portfolios of a customer to understand his payment history and discipline in consideration for new credit financing request (Vlok, 2017). With the growing probability of default, the use of credit payment history to assess customer payment profile becomes a useful source of information for the assessment of default risk. The collection, storage and analysis of this information by the lender could become a cost item that could lead to the increased cost of credit and cost in default. Credit check history utilization in financing decision may not accurately predict the likelihood of default but, it certainly helps lenders to understand risk profile for credit structure customization for maximum return on credit finance services. Vlok (2017) noted that credit checks and a computerized scoring system were not available around the early 1980s. Before the introduction of credit check history in the late 1980s, the assessment of credit applications for vehicle finance was done manually. This manual credit application assessment relied on human estimate judgement with potential for wrong estimate recorded long after the credit application approval.

\section{Research design and methodology}

This research utilized a descriptive research approach to collect and interprete quantative data to understand the interplay of collected data in relation to investigative problem (Nassaji, 2015). In this paper, respondents' perception of credit default was investigated and examined to understand default risk management requirement needed to minimize default risk and to maximize vehicle financing opportunities clients and financing companies. A survey method was applied to collect data from purposive randomly selected respondents in Cape Town. Because the vehicle finance industry applied the unified credit assessment policy, the data collected in Cape Town can be generalized country-wide. The quantitative data was collected from 381 respondents' customers of the four financial institutions in Cape Town to establish the relationship of the perception of the cost of credit default to lending and borrowing (Igwenagu, 2016). From a purposive ramdom sample of 400 respondents, a total of 381 respondents participated in the study. Participants were regular and walk-in customers of participating financial institutions who took time to complete closed ended questionnaires. Completed questionnaire were analysed using descriptive analysis and the result presented in tables and figures.

\subsection{Data Analysis}

The quantitative data was analysed using SPSS version 25 (IBM, USA) from a closed-ended questionnaire and exposed to descriptive analysis. Data was loaded on Microsoft Excel version 2019 and 


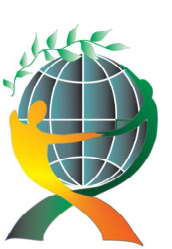

\author{
(online) $=$ ISSN $2285-3642$ \\ ISSN-L = $2285-3642$ \\ Journal of Economic Development, Environment and People \\ Volume 10, Issue 4, 2021
}

URL: http://jedep.spiruharet.ro

e-mail: office jedep@spiruharet.ro

coded accordingly. To understand relationships between variables, descriptive analysis using crosstabulation was applied to understand the perception of the cost of credit default (Devault, 2019). Unlike the logistic regression that predict outcomes of continuous categorical predictor variables, the descriptive analysis, described the cost of credit default variables based on respondents' perception (Sandro, 2014).

\title{
6. Results and discussions
}

This section describes responses received from the paper and discusses the influence of variables such as legal and administrative costs, customer losing confidence in the financial institution, bank listing customer on credit bureau, psychological problems and cost of credit default to the financial institution. The description utilizes tables and figures to show the relationship between multiple variables, the frequencies triangulated to improve understanding of respondents' perception of credit default.

The relationship between variables have a direct influence on the respondents' demographics: with $51 \%$ respondent are female and $41 \%$ male. Married couple at $47 \%$ likely agree that credit default is costly to customer. Most responpents earn between $31000-40000$ per annum. Younger respondents between the ages of $20-29$ years, likely agreed with the study. This descriptive study suggests an interesting pattern of mix perception and opinion of the cost of credit dafualt in vehicle financing.
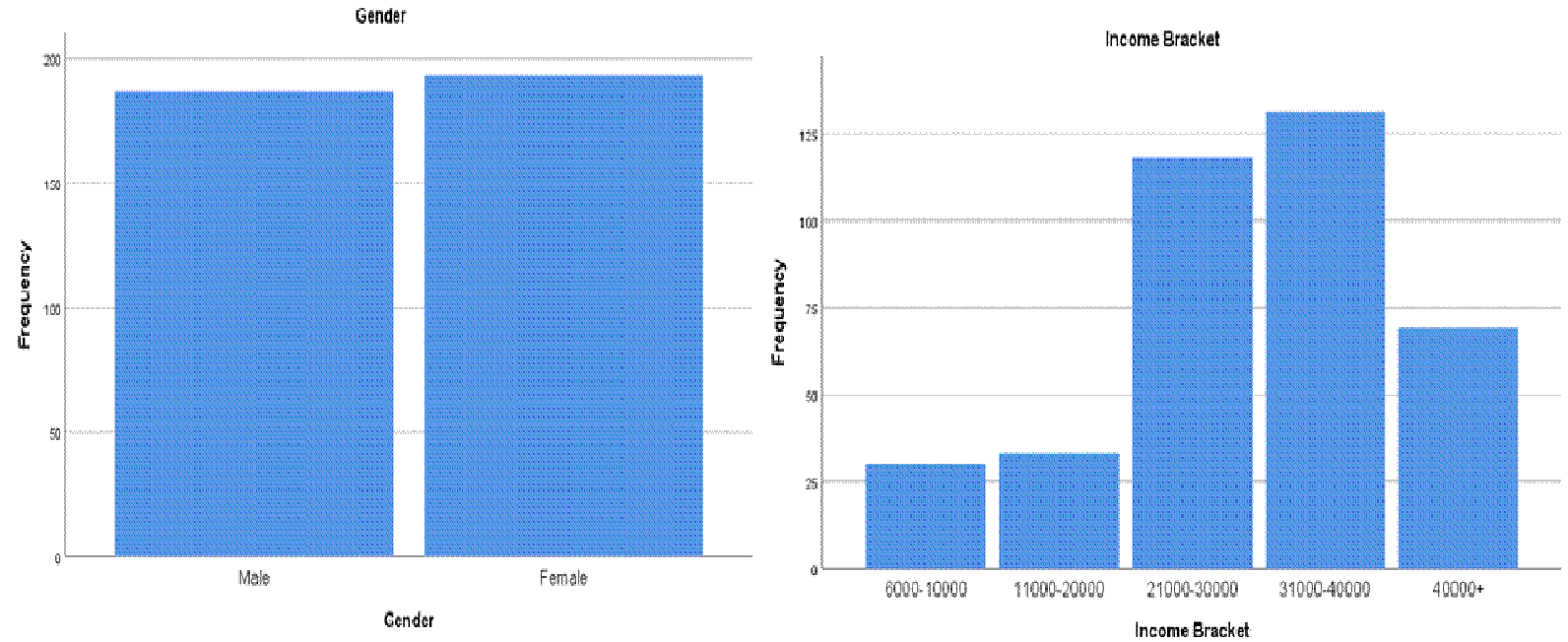

Figure 1: Gender and Income bracket 


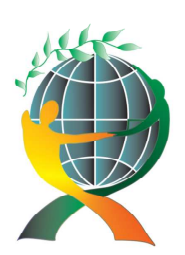

\author{
(online) $=$ ISSN $2285-3642$ \\ ISSN-L = $2285-3642$ \\ Journal of Economic Development, Environment and People \\ Volume 10, Issue 4, 2021 \\ URL: http://jedep.spiruharet.ro \\ e-mail: office jedep@spiruharet.ro
}

Gender: in figure 2 above, out of N381 respondents, 194 (51\%) were females and 187 were males (49\%). This suggests that the majority of respondents were females. This can also mean that more females were affected by the cost of credit default than their male counterparts.

Income bracket: The figure above illustrates that the income bracket of the majority respondents were between R31 000 - R40 000, followed by R21 000 - R30 000, and the last income bracket is R6000 R10000. This can also suggest that respondents in the income groups of R31 000-R40 000 were mostly affected by the cost of credit default compared to other income groups.

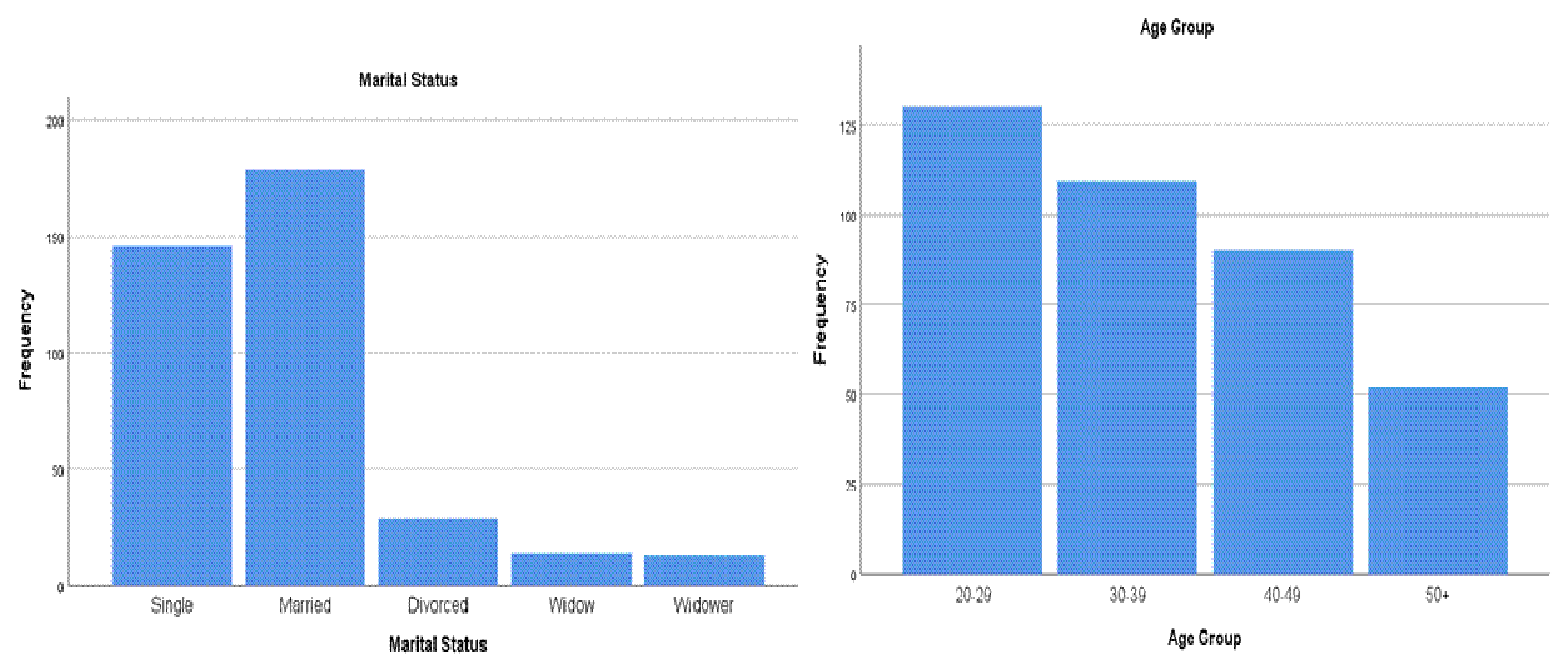

Figure 2: Marital staus and Age group

Marital status: The study comprised of 381 respondents of which 179 (47\%) are married, single 146 (38.3\%), divorces 29 (7.6\%), widows 14 (3.7\%) and widowers had 13 respondents which makes (3.4\%). The figure above shows that the majority of the respondents were married. 


\author{
(online) $=$ ISSN $2285-3642$ \\ ISSN-L = $2285-3642$ \\ Journal of Economic Development, Environment and People \\ Volume 10, Issue 4, 2021
}

URL: http://jedep.spiruharet.ro

e-mail: office jedep@spiruharet.ro

Age group: The age profile of the total sample N381 presented in the chart above explains that the majority of respondents were from the ages of 20-29 (34\%), followed by ages 30-39 (29\%). Furthermore, the ages $40-49$ comprised $24 \%$. The 50 years and older classification comprised only $14 \%$ of the respondents.

Figure 3 Cost of Credit Default to the financial institution.

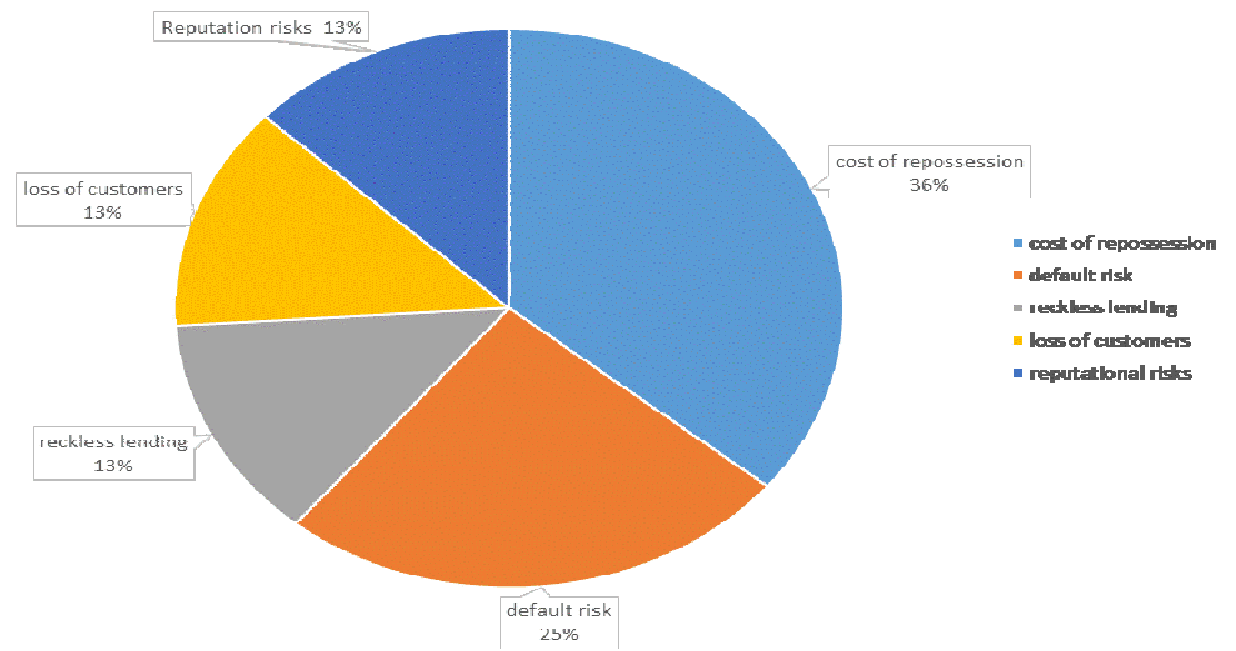

In presenting the cost of credit default as in figure 1.1 above, repossession cost is perceived to be the highest at $36 \%$. Reckless lending and loss of customer are lower at $13 \%$ as perceived by respondents, while reputation and default risk rates $13 \%$ and $25 \%$ respectively. The high and low representation of percentages as per the above figure remains a perception and not an actual cost of credit default to the financial institutions.

Table 1.1 Legal and administrative costs 


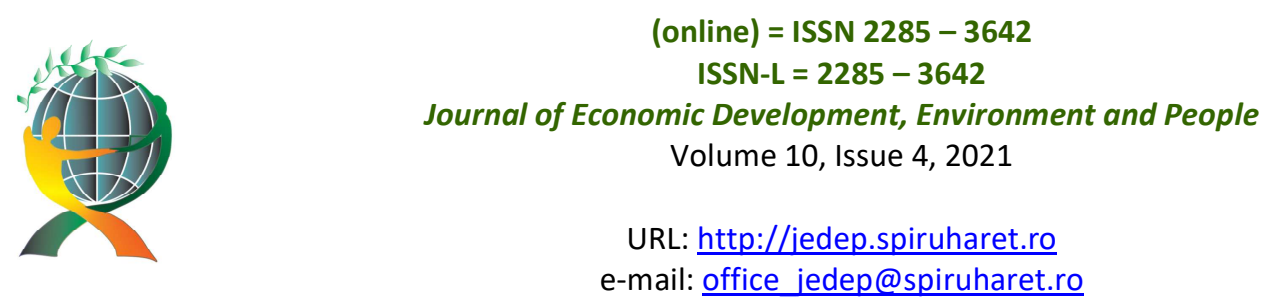

\begin{tabular}{|c|c|c|c|c|c|}
\hline & & Frequency & Percent & Valid Percent & $\begin{array}{c}\text { Cumulative } \\
\text { Percent }\end{array}$ \\
\hline \multirow[t]{6}{*}{ Valid } & highly likely & 83 & 21.8 & 21.8 & 21.8 \\
\hline & likely & 142 & 37.3 & 37.3 & 59.1 \\
\hline & unlikely & 113 & 29.7 & 29.7 & 88.7 \\
\hline & very unlikely & 41 & 10.8 & 10.8 & 99.5 \\
\hline & not at all & 2 & .5 & .5 & 100.0 \\
\hline & Total & 381 & 100.0 & 100.0 & \\
\hline
\end{tabular}

The legal and administrative cost in table 1.1, above presents a description of respondents' perception of the application of legal and administration cost in a default situation. The frequency distribution and discussion show that $37 \%$ of the N381 sample likely agreed that legal and administrative costs are an additional cost to the credit while only $0.5 \%$ did not agree at all. This is clearly evident that the most of respondents likely agreed that legal and administrative cost would likely increase the cost of credit when a customer has defaulted.

Table 1. 2 Bank listing customer on Credit Bureau

\begin{tabular}{llr|r|r|r} 
& & & & \multicolumn{2}{c}{$\begin{array}{c}\text { Cumulative } \\
\text { Percent }\end{array}$} \\
\hline \multirow{2}{*}{ Valid } & Frequency & Percent & Valid Percent & 18.4 \\
\cline { 2 - 7 } & highly likely & 70 & 18.4 & 18.4 & 59.1 \\
\cline { 2 - 7 } & Ilkely & 155 & 40.7 & 40.7 & 90.0 \\
\cline { 2 - 7 } & unlikely & 118 & 31.0 & 31.0 & 100.0 \\
\cline { 2 - 7 } & very unlikely & 38 & 10.0 & 10.0 & \\
\cline { 2 - 6 } & Total & 381 & 100.0 & 100.0 & \\
\hline
\end{tabular}

Bank listing customers on credit bureau is also one of the costs of credit default: as per table 1.2 above. The test was administered to N381 respondents' perception regarding bank listing customers on Transunion after default or multiple of defaults. Fourty one percent of respondents likely agreed and $31 \%$ unlikely agreed with the statement. According to the results $(41 \%)$ respondents between the ages of 20-29 agree that bank listing customers on credit bureau is an additional cost to the customer, $41 \%$ within the gender group were females. This descriptive means that females between the ages of 20-29 
agreed that bank listing customers on credit bureau is an additional cost of credit when a customer has defaulted.

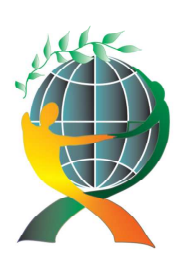

\author{
(online) $=$ ISSN $2285-3642$ \\ ISSN-L = $2285-3642$ \\ Journal of Economic Development, Environment and People \\ Volume 10, Issue 4, 2021
}

URL: http://jedep.spiruharet.ro

e-mail: office jedep@spiruharet.ro

Table 1. 4 Loss of confidence in the bank

\begin{tabular}{llr|r|r|r} 
& & & & & \multicolumn{2}{c}{$\begin{array}{c}\text { Cumulative } \\
\text { Percent }\end{array}$} \\
\hline \multirow{2}{*}{ Valid } & Frequency & Percent & Valld Percent & 18.4 \\
\cline { 2 - 7 } & highly likely & 70 & 18.4 & 18.4 & 58.0 \\
\cline { 2 - 7 } & likely & 151 & 39.6 & 39.6 & 90.6 \\
\cline { 2 - 6 } & unlikely & 124 & 32.5 & 32.5 & 100.0 \\
\cline { 2 - 6 } & very unlikely & 36 & 9.4 & 9.4 & \\
\cline { 2 - 6 } & & 381 & 100.0 & 100.0 & \\
\hline
\end{tabular}

The descriptive analysis shows that out of N381 respondents, $40 \%$ respondents likely agree that the costs of a repossession of a vehicle is perceived to be the loss of confidence in the bank and while only $9 \%$ of respondents thought it was very unlikely that the cost of a vehicle repossession is that a customer will lose confidence in the bank. However, $49 \%$ of respondents between the income brackets of R31000-R40000, aged 20-29 supported the perceived notion of repossession to mean loss of confidence in the bank.

Table 1. 5 Psychological problems

\begin{tabular}{ll|r|r|r|r} 
& & & & \multicolumn{2}{c}{$\begin{array}{c}\text { Cumulative } \\
\text { Percent }\end{array}$} \\
\hline Valid & Frequency & Percent & Valid Percent & \multicolumn{2}{c}{ highly likely } \\
\cline { 2 - 6 } & 68 & 17.8 & 17.8 & 17.8 \\
\hline likely & 145 & 38.1 & 38.1 & 55.9 \\
\hline unlikely & 114 & 29.9 & 29.9 & 85.8 \\
\hline very unlikely & 52 & 13.6 & 13.6 & 99.5 \\
\hline not at all & 2 & .5 & .5 & 100.0 \\
\hline Total & 381 & 100.0 & 100.0 & \\
\hline
\end{tabular}

Psychological problems are additional cost of credit. According to the frequency table above $38 \%$ likely agreed psychological problems are an additional costs when a vehicle is repossessed, $14 \%$ thinks that it is very unlikely and $0.5 \%$ do not agree at all. Using within group percentages, $40 \%$ of respondents with the ages of 20-29 likely agreed, females were the highest majority at $85 \%$. Therefore, the most females' ages 20-29 likely agreed that psychological problems are the additional cost to the customer 


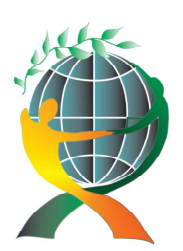

\author{
(online) $=$ ISSN $2285-3642$ \\ ISSN-L = $2285-3642$ \\ Journal of Economic Development, Environment and People \\ Volume 10, Issue 4, 2021 \\ URL: http://jedep.spiruharet.ro \\ e-mail: office jedep@spiruharet.ro
}

once the vehicle has been repossessed. However, the respondents at 50+ did not agree with the notion at all.

\title{
7. Conclusion
}

This paper described respondents' perception of the cost associated with default through the examination of responses received from 381 respondents who are customers of vehicle finance services in Cape Town, South Africa. The risk that the borrower may not fulfil his/her borrowing obligation is now better understood. This understanding presents credit owner (lender) with a default risk management opportunity to maximize the risk-adjusted rate of return and maintain minimum exposure to default associated cost. With the advent of technology, credit risks can be minimized because credit lending is not based on a hunch, but on the proper assessment of the borrower and market-related variables. This paper concludes that default in-vehicle credit financing is more likely to cause change in customer attitude and the economic condition. Although the perceived level of agreement is mixed and varied when triangulated against default possibility increases due to change in the personal and economic condition of the borrower. These conditions are: the economy, level of indebtedness, age, income, education and gender.

\section{Recommendations}

Based on the conclusion above, the following recommendations are suggested:

1) The implementation of default risk management intervention to mitigate credit default risk.

2) Further research that utilizes historical default data from Trans-union Credit Bureau for longitudinal analysis has to be explored.

3) Comparative analysis of default cost across biographical profiles of vehicle finance customers should be conducted with a view to getting a comprehensive understanding of the lending and borrowing process.

4) Development of a risk assessment formula to support and/ or replace current credit structure of vehicle financing is desirable and, therefore, must be designed. 


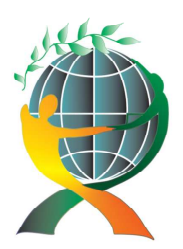

\section{References}

(1) Azariadis, C. 2018. Credit cycles and business cycles. https://doi.org/10.209955/r.2018.45-71 16 June 2018

(2) Basel Committee on Banking Supervision.2003. Copyright policy. http://www.bis.org/publ/bcbs98.htm [20 April 2018]

(3) Bonfim, D. 2007. Credit risk drivers: Evaluating the contribution of firm level information and macroeconomic dynamics. Unpublished Master thesis. Economic research department, Portugal.

(4) Brown, K. \& Moes, P. 2014 Credit Risk Management. Edinburgh Business School: UK

(5) Bolton, C. 2009. Logistic regression and its application in credit scoring. Unpublished PhD thesis, University of Pretoria, Pretoria.

Competition amongst banks good or bad? 2005. Economic perspectives for 2001. https://econpapers.repec.org. [16 May 2018]

(6) Credit Bureau Monitor. 2017. National Credit Act No 34 of 2005. www.ncr.org.za [17 June 2018]

(7) Crouhy, M., Galai, D. \& Mark, R. 2000. A Comparative analysis of current credit risk models. Journal of Banking \& Finance, 24:59-117.

(8) Davydenko, A.S. 2007. When do firms default? A study of the Default Boundary. Unpublished Master thesis, University of Toronto, Canada.

(9) Devault, G. 2019. Learn about using cross tabs in quantitative research. The balance small business: 19 March 2019.

(10) Duffee, G.R. 1999. Estimating the Price of Default Risk. Federal Reserve Board, 12(1):197-226, Spring.

(11) Dumbrava, V.2013. Using probability- Impact Matrix in Analysis and Risk Assessment Projects. Journal of Knowledge Management, Economics and Information Technology: 76-96, December.

(12) Giesecke, K. 2005. Default of Information. Journal of Economic Dynamics \&Control, 2281-2303, July.

(13) Gilbert, A.T. 2013. Analyzing financial risk management in Banks: Evidence of Liquidity, Credit and Capital risk in South Africa. Unpublished Master thesis, University of Eastern Mediterranean, North Cyprus. 
(14) Golafshani, N. 2003. Understanding reliability and validity in qualitative research. The Qualitative Report,

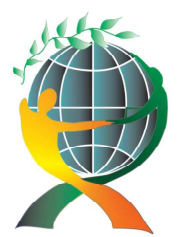

(online) = ISSN $2285-3642$

ISSN-L = $2285-3642$

Journal of Economic Development, Environment and People

Volume 10, Issue 4, 2021

URL: http://jedep.spiruharet.ro

e-mail: office jedep@spiruharet.ro

8(4):597-607, December.

(15) Gumparthi, S. 2010. Risk Assessment for Assessing NBFCs (Asset Financing) Customers. International of Trade and Finance, 1(1):2010-023X, June.

(16) Gunduz, Y., Memmel, C., \& Raupach, P. 2012. The common drivers of default risk. Deutsche Bundesbank, 36.

(17) Heimlich, E.J. \& Ardoin, M.N. 2008. Understanding behaviour to understand behaviour change. Environmental Education Research, 14(3):215-237, June.

(18) Igwenagu, C. 2016. Fundamentals of research methodology and data collection. https://www.researchgate.net/publication/303381524

[19 April 2019].

(19) Imbuga, M. 2012. An assessment of the effect of inflation on loan repayment among commercial banks. Unpublished Master thesis, University of Nairobi, Nairobi.

(20) Jacobs, L. 2017. Interview with the researcher on the 20 May 2017, Cape Town.

(21) Kealhofer, S. \& Rohn, R. J. 1993. Portfolio management of Default risk. San Francisco: KMV.

(22) Marcucci, J. \& Quagliariello, M. 2009. Asymmetric effects of the business cycle on the bank credit risk. Journal of Baking \& Finance, 33(9).

(23) Merton, R.C. 1973. On the pricing of corporate debt: The Risk structure of Interest Rates. American finance Association Meeting, December 1973. New York.

(24) Muzicek, P. 2010. Credit risk monitoring in the Czech Banking Sector. Early warning model. Unpublished Master thesis, Charles University, Prague.

(25) Nassaji, H. 2015. Qualitative and descriptive research: Data type vs data analysis. Language teaching research, 19(2):129-132, 2015.

(26) Naz, F. 2014. Word of mouth and its impact on marketing. International Journal of Scientific and Research Publications, 4(1):2250-3153, January.

(27) News 24. 2018. Explosive report into VBS Mutual Bank reveals large scale 'looting'.

https://www.news24.com/SouthAfrica/News/explosive-report-into-vbs-bank-reveals-large-scale-looting-

20181010.

[16 February 2019]. 


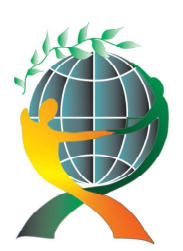

\author{
(online) $=$ ISSN $2285-3642$ \\ ISSN-L = 2285 - 3642 \\ Journal of Economic Development, Environment and People \\ Volume 10, Issue 4, 2021 \\ URL: http://jedep.spiruharet.ro \\ e-mail: office jedep@spiruharet.ro
}

(28) Norman, A.S. 2010. Importance of financial education in making informed decision on spending. Journal of Economics and International Finance, 2(10):199-207, October.

(29) NUS Risk Management Institute. 2014. African Bank goes under central bank's curatorship amidst mounting credit losses. https://rmicri.org/media/static/images/thumbnail-pdf/wcbaug05aug112014.pdf [7 August 2018].

(30) Paddy, J. 2012. Credit risk management in banking industry, Kwame Nkrumah Unpublished Master thesis, University of Science and Technology, Kwame Nkrumah.

(31) Qu, Y. 2006. Macro-Economic factors and probability of default. Unpublished Master thesis, Stockholm School of Economics, Stockholm.

(32) Quarterly Overview of Consumer credit trends released by Transunion South Africa. 2019. Transunion https://www.transunion.co.za/resources/transunion-za/doc/campaign/IIR/INT-AF-19-413140-IIR-Q1-2019/TU-IIRReport-Q1-2019.pdf [10 March 2019].

(33) Racine, F., Hart, J. \& Li, Q.I. 2006. Testing the significance of categorical predictor variables in nonparametric regression models. Paper presented at the 2002 International Conference on current advances and trends in nonparametric statistics, Crete, 20 March 2006.

(34) Rosch, D. 2005. The impirical comparison of default risk forecasts from alternative credit rating philosophies. International Journal of Forecasting, 21(2005):37-51.

(35) Rossouw, J. 2009. South African Reserve Bank History, Functions and institutional structure, Pretoria.

(36) SA Consumer Credit Index. 2018. Transunion.

https://www.transunion.co.za/resource/transunion-za/doc/campaign/CCI/INT-af-18-265801-cci-q2-2018/TU-CCIReport-Q2-2018.pdf [18 November 2018].

(37) Schularick, M. \& Taylor, A.M. 2012. Credit booms gone bust: Monetary policy, leverage cycles, and financial crisis, 1870-2008. American Economic Review, 102(2):1029-1061.

(38) Schwarz, A. 2011. Measuring, Monitoring and Forecasting of Consumer Credit Default Risk. Germany: Shumpeter.

(39) Schwartz, J.A. 2002. Asset Price Inflation and Monetary Policy. National bureau of Economic Research, 52:829852.

(40) South Africa Government. 2015. National Credit Regulations including Affordability Assessment. Notice 202 of 2015. Government Gazette, 38557: 37, March 13. 

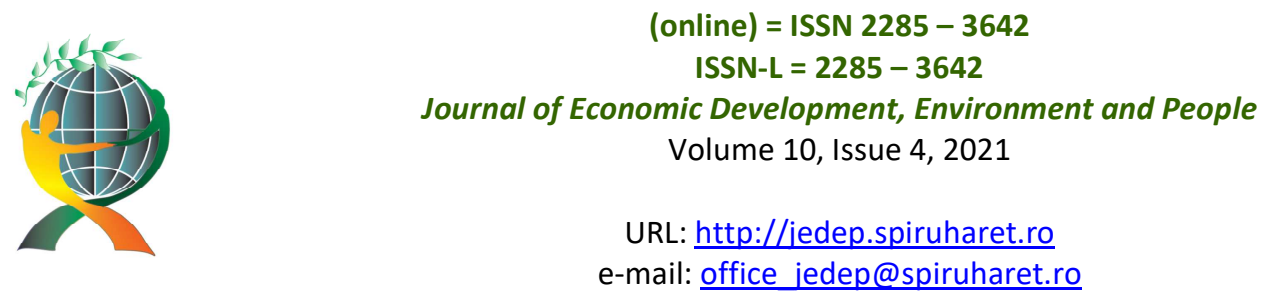

(41) Stiglitz, J.E. \& Weiss, A. 1981. Credit rationing in market with imperfect information. The American Economic Review, 393-410, June.

(42) Van Zyl, E. 2010. Bank overcharging black home owners. Weekend Argus: 21 November 2010.

(43) Vassalou, M. \& Xing, Y. 2002. Default risk in equity returns. Columbia: Columbia University.

(44) Verick, S. \& Islam, I. 2010. The great recession of 2008-2009: Causes, consequences and policy responses. Griffith: Griffith University.

(45) Vlok, D. 2017. Interview with the researcher on the 16 May 2017, Cape Town.

(46) Vojtek, M. \& Kocenda, E. 2011. Default Predictors in Retail Credit Scoring: Evidence from Czech Banking Data. Paper presented at the William Davidson Institute, University of Michigan, Canada. April 2011.

(47) Weiss, L.A. 1990. Bankruptcy Resolution: Direct costs and violation of priority of claims. Journal of Finance Economics, 285-312, July.

(48) Wentzel, A. 2015. Financial Literary in South Africa. Reviewed in: International Handbook of Financial Literacy, 329-339, March.

(49) Zabia, A. 2019. Managing Default Risk. www.bis.org [7 August 2019]. 